\title{
Urdimento
}

Revista de Estudos em Artes Cênicas E-ISSN: 2358.6958

\section{Um crítico e uma prostituta: Incursões do pensamento em direção ao espectador qualquer}

Luiz Paulo Pimentel de Souza

\section{Para citar este artigo:}

SOUZA, Luiz Paulo Pimentel. Um crítico e uma prostituta: Incursões do pensamento em direção ao espectador qualquer. Urdimento, Florianópolis, v. 1, n. 40, mar./abr. 2021.

do) DOI: http:/dx.doi.org/10.5965/1414573101402021e0205

Este artigo passou pelo Plagiarism Detection Software | iThenticate 
Um crítico e uma prostituta:

Incursões do pensamento em direção ao espectador qualquer

Luiz Paulo Pimentel de Souza

\begin{abstract}
Resumo
A partir da pergunta feita por Virginia Woolf em seu ensaio Como se deve ler um livro? e de seu vivo interesse pela figura do leitor comum, neste artigo deslocamos a análise do campo literário para o teatral de modo a problematizar a figura do espectador. Com o intuito de investigar as singularidades e potencialidades das quais o olhar do espectador comum (propositalmente enfocado aqui como espectador qualquer) estaria investido, o artigo mobiliza dois personagens: um crítico, descrito por Diderot em seu Discurso sobre a poesia dramática como um espectador ideal, e uma prostituta aficionada por tragédias gregas, interpretada pela atriz Melina Mercouri no filme Nunca aos Domingos, de Jules Dassin. Buscando diferir o olhar do espectador comum daquele que seria o seu extremo oposto, o especialista, especificamos dois procedimentos distintos presentes na relação entre o olhar e a obra: o gesto hermenêutico, articulando o saber a partir de um campo transcendental, e o gesto-qualquer, recusando exterioridades e fundando um espaço de imanência.
\end{abstract}

Palavras-chave: Recepção teatral. Espectador. Crítica teatral. Singularidade qualquer.

A critic and a prostitute:

Incursions of thinking towards the whatever-singularity spectator

\begin{abstract}
Starting with Virginia Wolf's question which gives name to her essay How should one read a book? and her vivid interest in the figure of the common reader, this article aims to displace her analytical approach from the literary field to the theatrical field, so as to problematize the spectator figure. Intending to investigate the singularities and potentialities which are invested in the eyes of common spectators (deliberately focused as a spectator of whatever-singularity here), the article mobilizes two characters: a critic who is described as an ideal spectator in Diderot's Discourse on Dramatic Poetry, and a prostitute who is passionate about Greek tragedies, played by the actress Melina Mercouri on Jules Dassin's movie Never on Sunday. Seeking to distinguish the eye of the common spectator from the eye of that who is supposed to be his opposite - the specialist -, this article indicates two distinctive procedures both present in the relationship between regard and work of art: the hermeneutic gesture that articulates knowledge from a transcendental field and the whatever-singularity gesture that refuses exteriorities and establishes a sphere of immanence.
\end{abstract}

Keywords: Theatrical reception. Spectator. Theatre criticism. Whatever-singularity.

1 Ator, dramaturgo e pesquisador em Artes Cênicas. Formado em Interpretação Teatral pela Escola de Comunicações e Artes da Universidade de São Paulo, mestre em Filosofia e Educação pela Faculdade de Educação da USP. Doutorando do Programa de Pós-Graduação em Artes Cênicas (ECA/USP). luiz.pimentel.souza@gmail.com

http://lattes.cnpq.br/5040275993735496

https://orcid.org/0000-0001-9160-9003 
Un crítico y una prostituta:

Incursiones de pensamiento hacia el espectador cualsea

\section{Resumen}

De la pregunta formulada por Virginia Woolf en su ensayo How should one real a book? y su gran interés en la figura del lector común, en este artículo cambiamos el análisis del campo literario al teatral para problematizar la figura del espectador. Para investigar las singularidades y potencialidades en las que se invertiría la visión del espectador común (enfocado deliberadamente aquí como un espectador cualsea), el artículo moviliza dos personajes: un crítico, descrito por Diderot en su Discurso sobre la poesía dramática como un espectador ideal y una prostituta aficionada a las tragedias griegas, interpretada por la actriz Melina Mercouri en la película Never on Sundays, de Jules Dassin. Buscando diferenciar la mirada del espectador común de la que sería su extremo opuesto, el especialista, especificamos dos procedimientos distintos presentes en la relación entre la mirada y el trabajo: el gesto hermenéutico, articulando el conocimiento desde un campo trascendental, y el gesto-cualsea, rechazando exterioridades y fundando un espacio de inmanencia

Palabras clave: Recepción teatral. Espectador. Crítica teatral. Singularidad cualsea. 
Como se deve ler um livro? é a pergunta e o nome de um ensaio de Virginia Woolf (2014, p. 164):

Quero enfatizar, antes de tudo, o ponto de interrogação no fim do meu título. Ainda que eu pudesse responder para uso próprio à pergunta, a resposta só se aplicaria a mim, não a você. De fato, o único conselho sobre leitura que uma pessoa pode dar a outra é não aceitar conselho algum, seguir os próprios instintos, usar o próprio bom senso e tirar suas próprias conclusões. Se nos pusermos de acordo quanto a isso, sinto-me em condições de apresentar algumas ideias e lhes fazer sugestões, pois você assim não permitirá que elas restrinjam a característica mais importante que um leitor pode ter, sua independência.

Publicado pela primeira vez em 1926 na revista da Universidade Yale, o ensaio pode ser dividido em três partes. A primeira delas consiste em recusar de largada a procura da resposta à pergunta-título nos especialistas, críticos e professores universitários. Woolf afirma que tais personagens tendem a formalizar demasiadas regras para o ato da leitura: "admitir autoridades em nossas bibliotecas, por mais embecadas e empelicadas que estejam, e deixar que elas nos digam como ler, o que ler e que valor atribuir ao que lemos, é destruir o espírito de liberdade que dá alento a esses santuários" (Woolf, 2014, p. 164). A escritora, no entanto, faz um apelo à prudência: defende a liberdade do leitor, mas, ainda assim, orienta o cultivo de certo controle na relação com os livros. Na segunda parte do texto ela passa a justificar a demanda dessa cautela: trata-se de uma estratégia para preservar as forças daquele que lê na presença do amontoado das coisas escritas por homens e mulheres de todas as raças, línguas, idades e temperamentos. Diante do monumental e prolífico vozerio proveniente dos livros escritos, o leitor deve estar disposto a disciplinar suas forças de maneira rigorosa e enérgica para atingir o que Woolf nomeia como "ponto certo" do uso dessa potência.

Neste momento, um novo problema teórico emerge no ensaio de Woolf: a autora nos diz que, em relação aos livros, o leitor não deve se submeter jamais às regras exteriores elaboradas pelos professores; entretanto, afirma que ele também não deve se entregar a uma liberdade sem limites, com o risco de que se encontre rapidamente exaurido de sua potência. É justamente na tensão entre o enfrentamento da autoridade dos especialistas que normatizam os sentidos dos 
livros - autoridade essa que ela recusa sem ressalvas - e seu intuito como escritora de meditar sobre o "ponto certo" do uso da potência do leitor que Woolf passa a expor uma série de conselhos sobre possíveis modos de se relacionar com os escritos alheios. Advém dessa meditação, localizada na terceira parte do texto, uma série de exercícios elencados pela escritora que mobilizam o corpo e o espírito de quem lê: deambulação ao acaso e sem qualquer finalidade pelas estantes de uma biblioteca; comparação entre obras e estilos literários; leitura e escrita como modo de experimentar a dificuldade de compor cada gênero textual; atenção aos impulsos sensíveis na relação com o livro (prazer, ódio, tédio); abandono da leitura, sem qualquer tipo de culpa; saída para caminhadas ou para dormir etc. É para levar a cabo a ideia de uma liberdade que zela pela potência do leitor em sua relação com o livro que Woolf investe na prática de exercícios, com suas respectivas consequências filosóficas, como modo de transformação dessa relação: o próprio exercício da leitura pensado como prática de ascese em vez da aposta na normativa hermenêutica proveniente do discurso especialista.

A pergunta sobre como se deve ler um livro não é nada nova para o pensamento Ocidental. Entretanto, digno de nota é também o fato de que o ensaio de Woolf foi incluído pela autora na segunda edição do livro O leitor comum, coletânea de textos publicado pela primeira vez em 1925. Neste ensaio, tal como no anterior, o título nos remete a algumas perguntas: qual seria a natureza deste tipo de leitor, o leitor comum? A quais outros tipos de leitores o leitor comum se oporia? Qual especificidade Woolf atribui à ideia de comum? Se a pergunta sobre modos de ler livros não é nada inédita, a emergência dessa personagem, o leitor comum, parece ser um traço bastante específico de uma época.

De largada, tal personagem é descrita por Woolf como uma pessoa qualquer que habita um cômodo qualquer, não necessariamente uma biblioteca, e que não teria sido corrompida por preconceitos literários. De modo diverso do erudito e do crítico, ela não seria tão instruída e nem dotada pela natureza de modelos mais refinados de leitura. Muitas vezes, leria de modo apressado, superficial e inexato. No entanto, a escritora indica duas qualidades dessa figura que nos parecem fundamentais: ela lê por prazer, e não para transmitir conhecimentos ou corrigir 
opiniões sobre o lido, e, ao ler, constrói para si o retrato de uma pessoa, época ou uma teoria singular sobre a arte da escrita.

Ler por prazer e para si. Eis no que constitui o singular modo de leitura daquela pessoa qualquer que Woolf chama de leitor comum. Não à toa, a autora faz uso dessa personagem conceitual para nomear sua coletânea que traz em seu interior uma pergunta tal como como se deve ler um livro? Parece-nos que, ao escrever, a autora também quer ser vista, ela mesma, como uma escritora que ensaia a partir de sua posição de leitora comum. Talvez, seja guiada por seu próprio prazer e lendo para si que Woolf escreve textos sobre livros, cautelas, exercícios e possíveis modos de ativar certa potência na relação com os escritos do mundo.

O presente artigo enseja se filiar às problemáticas delineadas por Woolf em ambos os ensaios abordados e pretende realizar, de modo experimental, um deslocamento dos termos em questão: não mais nos deteremos sobre o encontro entre leitor e livro, mas focaremos nossa atenção na relação estabelecida entre o espectador e a cena teatral. De modo diverso ao de Woolf, não pretendemos seguir pela via que elenca conselhos para responder a uma questão do tipo como se deve ler uma ação cênica? Entretanto, podemos afirmar que nos interessa, sim, a pergunta sobre o como, ou seja, nossa problemática se circunscreve à questão do modo: buscamos investigar alguns modos possiveis de composição do olhar do espectador teatral e quais as consequências de tais modos em relação à experiência do espectador. Ainda, do mesmo modo como interessou a autora, também temos interesse em pensar a respeito do espectador comum. Uma das tentativas para destacar esse modo outro de se constituir como espectador será trazer para a cena deste artigo o seu contrário: o espectador raro, formalizado na figura do especialista. Por meio de um jogo de contrastes, buscamos identificar procedimentos teóricos distintos que configuram tais modos de se constituir como espectador.

Para empreender nossa busca é preciso estabelecer duas ressalvas iniciais. Antes de tudo, entendemos que diferentes modos implicam obrigatoriamente diferentes práticas, exercícios e campos de saber. Tem-se aí uma questão de ordem artística e também pedagógica: como se produz certo modo de olhar; por 
quais exercícios passa o corpo e quais são os saberes que formalizam um espectador cuja atitude corresponde a certo modo de agir e não a outro? Portanto, o tema da educação e os modos de condução da conduta e do olhar alheio serão pontos de análise a se destacar em nosso artigo. Há também outra questão fulcral: tais modos de configurar o olhar também implicam diferentes formas de constituição de sujeitos possíveis. Ou seja, entendemos que tais campos de produção de saberes e modos de olhar resultam diretamente na formação de subjetividades específicas.

Para armar um campo de pensamento que nos permita destacar a questão dos diferentes modos de composição do olhar do espectador, buscaremos avizinhar duas personagens conceituais presentes em nosso título e provenientes de fontes distintas. A primeira delas consiste em Aristo, um homem das letras que é assombrado por um problema do pensamento, e que aparece descrito no tratado teórico sobre o teatro intitulado Discurso sobre a poesia dramática (2005), escrito por Denis Diderot. Desse texto sobrevém uma extensa meditação sobre o que deve vir a constituir determinado modo de olhar de um espectador bastante específico: o crítico teatral. A segunda personagem provém de uma obra cinematográfica: o filme Nunca aos Domingos, de Jules Dassin. Dele extraímos o modo de ser espectadora da protagonista da narrativa, a prostituta Illya, interpretada pela atriz grega Melina Mercouri.

\section{Um crítico}

O filósofo e enciclopedista francês Denis Diderot deteve-se demoradamente nos assuntos teatrais especificamente em duas de suas obras: O paradoxo do comediante (2006) e Discurso sobre a poesia dramática (2005). Em suas meditações a respeito do teatro, Diderot faz uma curiosa defesa a respeito de uma nova e conflitante figura no debate intelectual francês do século XVIII. Trata-se do crítico teatral.

Um curto fragmento presente no Discurso intitulado Dos autores e dos 
críticos principia rechaçando por completo a figura dos críticos teatrais da época, assim como a figura do autor de peças:

O papel de um autor é um papel bem inútil: é do homem que se crê em condições de dar lições ao público. E o papel do crítico? É ainda bem mais inútil: é o do homem que se crê em condições de dar lições àquele que se crê em condições de dá-las ao público (Diderot, 2005, p. 125).

Se o autor de peças diria ser o mestre do público, o crítico, por sua vez, reclamaria o papel de mestre do mestre, numa batalha contínua. Uma existência metanarrativa supérflua, portanto. Ao público que pudesse escapar da soberba dos críticos por meio da assunção de seu próprio partido, caberia escutar os brados dos expertos. Exclamaria o crítico: "Ó tempo! Ó costumes! O gosto perdeuse!" (Diderot, 2005, p. 125), e, então, ele poderia se consolar em sua própria e superior sabedoria.

Entretanto, longe de querer combater a instituição da crítica de arte em si, a posição de Diderot trata mais de lamentar a parca instrução dos vaidosos críticos de seu presente. O que ele desaprova, portanto, é o modo como a crítica é feita. Segundo o filósofo, em contraposição aos críticos antigos que começavam sua educação pela filosofia, migrando posteriormente para a carreira das letras, o crítico setecentista teria demasiada pressa em aparecer publicamente e tomar a pena para rabiscar suas opiniões. A correção necessária para uma atuação crítica legítima, sustenta Diderot, aconteceria apenas mediante uma intensa formação “conselhos, lima e tempo" (Diderot, 2005, p. 126).

Indo além, o pensador francês descreve as belas artes sustentadas por dois pilares fundamentais: a verdade e a virtude. Partindo desse pressuposto, o início da formação de um crítico passaria por sua conversão moral, visando firmar-se como uma pessoa de bem. Dessa maneira, Diderot acabaria por participar do processo que produziria uma derradeira cisão entre seres que estariam aptos e outros que, por sua vez, se encontrariam inaptos para emitir algum juízo no campo das práticas teatrais. Ainda, segundo Diderot, às pessoas infames (avarentos, maus pais, maus filhos, maus cidadãos, supersticiosos e hipócritas) seria impossível a 
produção de qualquer coisa de valor como as belas artes. Diderot diz, então, ao homem bem-nascido, dotado de um espírito reto e coração sensível pela natureza:

[...] abandona por um tempo a sociedade dos homens; vai estudar-te a ti mesmo. Estando desafinado, como proporcionará o instrumento uma doce sinfonia? [...] Da perfeição moral que estabeleceres em teu caráter e teus costumes, brotará uma nuança de grandeza que se derramará sobre tudo que escreveres (Diderot, 2005, p. 127).

Em vista desse apelo a um trabalho de um sobre si mesmo, justamente a esse exercício predominantemente pedagógico, como meta para a formação do crítico de arte, Diderot conclama seu alter ego Aristo, de maneira a narrar um exemplo desse processo de edificação moral. O filósofo, então, descreve uma intrigante meditação de Aristo, cujo saldo final residiria em uma transformação radical na acepção da figura do crítico de teatro.

Aristo é descrito como um homem de 40 anos que se dedicou ao longo da vida ao estudo da filosofia. Tendo nascido com sua alma honesta e sem ambição, coube-lhe o título de filósofo por seu comportamento austero, sua simplicidade nos discursos e seu modo de vida pobre e feliz na pobreza. Certo dia, encurralado por um problema de pensamento, Aristo decide passear sozinho para poder meditar sobre alguns assuntos.

O alter ego de Diderot, ao longo de seu passeio, expõe sua aflição: é ignorante em poder dizer o que é o verdadeiro, o bom e o belo. Sua inaptidão em dizer a verdade desses objetos o faz tremer por não poder mais ser chamado de filósofo. Então, Aristo passa a meditar sobre o que pode fundar a capacidade de julgar e de distinguir uma boa obra de uma má.

A primeira incursão do pensamento de Aristo trata de definir a impossibilidade de qualquer acordo de juízo estético entre as pessoas. Assumindo a permanente ignorância a que o ser humano está condenado, o homem angustiado afirma existir entre as pessoas apenas variação e nenhuma regra:

Não há talvez, em toda a espécie humana, dois indivíduos que tenham alguma semelhança aproximada. [...] O espírito, a imaginação, a memória, 
as ideias, as verdades, os preconceitos, os alimentos, os exercícios, os conhecimentos, os estados, a educação, os gostos, a fortuna, os talentos têm sua variedade. [...] Portanto, como seria possível que dois homens tivessem precisamente o mesmo gosto ou as mesmas reações do verdadeiro, do bom e do belo? A diferença da vida e a variedade dos acontecimentos bastariam para diferenciar e variar os julgamentos (Diderot, 2005, p. 128).

Aristo ainda transfere essa variação infinita entre os indivíduos para sua própria vida: "Talvez não me reste, na idade que tenho, uma só das moléculas que trazia no corpo ao nascer" (Diderot, 2005, p. 128). A condição de todas as pessoas seria, assim, balbuciar na infância, crescer, raciocinar e, depois, voltar a balbuciar. Dessa maneira, estaria a humanidade condenada a jamais pôr-se de acordo com seus semelhantes na emissão de um juízo de gosto permanente.

A imagem da ignorância, dessemelhança e dissenso entre as pessoas é interrompida pela primeira pausa no raciocínio de Aristo. O silêncio da figura demarca não somente sua melancolia, mas também sua recusa em se contentar com o mundo ruidoso descrito previamente. Seu pensamento é retomado com o intuito de encontrar uma medida fora de si mesmo e da sensibilidade variante dos indivíduos que pudesse definir um juízo válido para todos. Ora, seria necessário, de acordo com Aristo, a criação de uma pessoa ideal que resguardasse a medida de todas as medidas. Entretanto, pensa Aristo, a criação dessa pessoa estaria submetida à sua imaginação, ou seja, ao caos sensível pré-visualizado. Ao mesmo tempo, a solução para a celeuma seria criar tal indivíduo a partir de elementos constantes. Mas onde estes se encontrariam?

Em meio a uma proliferação de pensamentos reticentes, Aristo pausa de novo o seu raciocínio. Mais longa do que a primeira, a segunda meditação constrói um arcabouço de ideias que afirmam ser a única estratégia possível a criação de uma idealidade de pessoa para cada ofício. Assim como os escultores, seria preciso organizar um modelo de pessoa perfeita em sua moral. Mais além, tal modelo deveria ser um profundo conhecedor de uma série de saberes:

Que o homem de letras faça o modelo ideal do homem de letras mais acabado, e que julgue pela boca desse homem as produções dos outros 
e as suas. Que o filósofo siga o mesmo caminho. Tudo o que parecer bom e belo para este modelo, assim será. Tudo o que the parecer falso, ruim e disforme, assim será. [...] O modelo ideal será tanto mais severo quanto mais se estenderem seus conhecimentos (Diderot, 2005, p. 130).

Tal modelo, impraticável por conta de sua idealidade, deveria ser transformado conforme as circunstâncias. Mesmo projetando um crivo inatingível, seria preciso que o crítico se esforçasse, por meio de seus estudos, para poder figurar-se mais próximo do ideal.

Após o solilóquio, Diderot nos conta que Aristo compreendeu que ainda tinha muito a aprender. Também nos conta o fato curioso de que o pensador melancólico voltou para sua casa e lá se trancou por 15 anos. Como Aristo teria passado esses tantos anos de solidão? Dedicando-se tenazmente aos estudos da história, da filosofia, da moral, das ciências e das artes. Aos 55 anos, o recluso saiu de sua casa transformado: havia se tornado um homem de bem, cultivado, um verdadeiro homem de gosto que seria não somente um grande autor, mas o melhor dos críticos (Diderot, 2005).

A parábola de Diderot chama menos atenção pela linha de constância de juízo que atribui à humanidade e mais pela descrição do exercício pelo qual se formaria o olhar dessa espécie de espectador ideal, ou seja, o crítico de teatro. As duas pausas do raciocínio de Aristo abririam espaço para a transformação de seu objeto de análise (a possibilidade, ou não, de um juízo crítico geral para as artes) e passariam a tornar possível o que antes parecia inimaginável. Segundo o filósofo francês, para se formar como uma pessoa de gosto, o aspirante a crítico deveria organizar ao redor de si um espaço composto por dois vetores de atenção: a solidão e um trabalho permanente de estudo e aperfeiçoamento. Menos presente no mundo público do que no privado, o crítico, para ser considerado a partir de alguma legitimidade, deveria se prestar não somente a uma formação contínua, mas a uma erudição geral em várias outras ciências e campos de saber. Ora, parece ser bastante inédita, à época de Diderot, essa acepção de um sujeito da cultura, cuja manifestação se dá a partir de algum gesto crítico, que alcança seu estatuto de qualidade não somente se diferenciando de todo um rol social taxado 
a partir da insígnia da infâmia como também pelo condicionamento a uma vida de formação intelectual contínua. Para Diderot, ser bom crítico, um espectador ideal, depende do exercício obstinado do estudo. A aposta na erudição é, aqui, vertical. Posição nada surpreendente para um autor que escrevia a Enciclopédia elaborada como um modo de combater saberes supersticiosos e reivindicar a verdade científica como base para o pensamento ocidental.

Diderot acaba, portanto, por sugerir toda uma trajetória de legitimação do modo de ser espectador do crítico pautada por uma justificativa de ordem pedagógica. A figura do crítico idealizada por Aristo passa a pressupor uma formação intensa, recusando qualquer tropeço na ignorância, de modo a efetivar um ser distinto do mundo das pessoas viciosas e infames. Nesse sentido, o objetivo da formação do olhar tem uma direção bastante evidente: produzir um homem distinto, uma pessoa de bom gosto². Além da perseguição desse ponto de perfeição do gosto, é preciso notar que Aristo está emaranhado em outro problema: sua formação intelectual, por mais lapidada que seja, é vista como em perpétua falta. O bom gosto, os ideais, a excelência, nada disso está à sua mão. Ele está, ao contrário, condenado a se mover no interior de uma maquinaria pedagógica que opera da seguinte forma: cada passo que dá em direção a esses alvos faz com que eles novamente escapem, tornando-se mais uma vez distantes. Observamos, assim, emergir a figura desse tipo de crítico que está permanentemente em falta com sua própria vida e formação e, portanto, sempre em processo educativo. Destarte, de acordo com Diderot, o bom crítico seria justamente aquele que vive todos os dias o conflito de não estar preparado o suficiente para julgar, ao mesmo tempo em que cotidianamente trabalha na edificação de sua própria instrução e emissão do seu juízo final.

Eternidade, falta, bom gosto, correção moral, juízo final: está armado o léxico - um tanto cristão, um tanto burguês, como se nota - que vai sustentar tanto as bases de formação do crítico teatral excelente como um modo de se estruturar determinado processo pedagógico. Observemos como esse apelo de um

2 Sobre a importante questão do gosto nas sociedades europeias a partir do século XVII, recomendamos a leitura do livro O homem sem conteúdo, de Giorgio Agamben (2013a), em especial o capítulo O homem de gosto e a dialética da dilaceração. 
conhecimento e uma pedagogia que se fundam numa perspectiva transcendental vai dotar o saber nascido de um gesto bastante comum e simples - o ato de olhar - de um aspecto em tudo exterior ao sujeito que olha, ao mesmo tempo que o investe de autoridade própria para dizer o ponto justo ou não de uma obra.

Devemos lembrar, entretanto, que Aristo é melancólico e chega ao final da parábola outra vez imerso em seu desânimo. Esse aspecto soturno parece estar sustentado por uma dupla percepção: o fardo de estar condenado em sua formação contínua e insuficiente ad aeternum e o fato de que, por mais que se dedique dia após dia ao estudo, cada pessoa sobre a terra segue infinitamente distinta das outras e também de si mesma ao longo da vida, impossibilitando a formação efetiva de qualquer juízo geral sobre algo.

\section{Uma prostituta}

É no livro X das Metamorfoses que Ovídio (2017) nos conta o mito de Pigmalião. Rei da ilha de Chipre e escultor, ficou conhecido por talhar uma estátua ambicionando produzir a imagem da mulher ideal, uma vez que havia decidido viver em celibato por ser contrário às atitudes morais das prostitutas que habitavam sua ilha. Imediatamente apaixonado por sua própria criação, Pigmalião passou a adorná-la de anéis, presentes e ouro. A deusa Afrodite, compadecida ao ver o tamanho do afinco com o qual tal homem era devoto da imagem criada por si mesmo, insuflou o gesso com vida e ambos, criador e criatura, passaram a consumar seu amor e gerar seres nascidos dessa relação.

Ao longo da modernidade, o mito foi retomado pela filosofia, psicologia e, evidentemente, pelo teatro: Pigmalião (2011) é o título de uma peça escrita pelo dramaturgo irlandês Bernard Shaw também tornada célebre por sua adaptação cinematográfica sob a forma de um filme musical intitulado My fair lady. Em seu arco narrativo, o dramaturgo nada fala sobre Chipre, reis ou estátuas. Deslocando a ação para a Londres do começo do século XX, Shaw nos apresenta o encontro entre uma florista de rua qualquer, Eliza Doolittle, e um culto professor de fonética, Henry Higgins. Sem que ela saiba, o intelectual a estuda em seu trabalho nas ruas 
e grava as formas com as quais ela pronuncia a língua inglesa. Percebendo-se por acaso alvo do trabalho do professor, a florista se rebela, ao que ele retruca que uma existência tão infame quanto a dela atestaria um crime para o sucesso de uma língua tão evoluída quanto a inglesa. É aí que o professor anuncia que se sente capaz de levar a cabo uma missão necessária: transformar a vendedora de flores em uma alta dama da sociedade num curto espaço de tempo.

HIGGINS: Vê, por exemplo, esta criatura com esse inglês de sarjeta. Esse modo de falar vai conservá-la na sarjeta até o fim de seus dias. Pois olha, cavalheiro, em três meses eu podia fazer essa garota passar por duquesa numa recepção de qualquer grande embaixada. Podia até arranjar para ela um lugar de governanta ou gerente de loja, atividades que exigem um inglês muito melhor (Shaw, 2011, p. 27).

No dia seguinte ao encontro, a própria moça decide se submeter a essa espécie de conversão intelectual e comportamental e se dirige à casa do professor. Higgins é uma figura fundamental na ação da peça. Esse cientista da fala, juiz do dizer - especificamente em seu aspecto fonético -, é também um pedagogo. E, mais além, um pedagogo com plena consciência de quais são os modos mais e menos corretos de se portar e discursar em relação à realidade.

A peça culmina em um rompimento radical entre a florista, tornada agora uma dama refinada da sociedade, e o professor de fonética. Entretanto, quando pedem a ela para que se vingue do processo pedagógico humilhante do qual foi cobaia e responda com violência às ofensas que Henry Higgins lança sobre ela, Eliza se percebe presa numa ação limitada:

ELIZA: Não posso. Antes eu podia; mas agora já não sei mais como voltar pra trás. O senhor me disse, se lembra, que quando uma criança chega a um país estrangeiro, aprende logo a nova língua e esquece a língua nativa. Eu sou uma criança que chegou ao país da boa educação. Esqueci a linguagem com que nasci. Agora só sei falar esta (Shaw, 2011, p. 139).

Protagonizado pela atriz grega Melina Mercouri e dirigido pelo estadunidense Jules Dassin, o filme Nunca aos domingos (Never on Sunday, 1960) relê ao mesmo tempo o mito de Pigmalião e a peça de Bernard Shaw. Seu enredo apresenta 
novamente a figura de um intelectual, no caso o estadunidense Homer Thrace, interpretado pelo próprio Dassin, que parte para Atenas em busca da experiência quase mística de entrar em contato com os princípios da cultura Ocidental. Lá, onde esperava encontrar um povo filósofo, ele se depara com gente comum, vivendo o cotidiano de trabalho portuário. Decepcionado com essa gente simplória, ele conhece Illya, uma prostituta autônoma que escolhe seus próprios clientes. Para o intelectual, ela possui o frescor essencial da vitalidade grega, mesmo vivendo de uma profissão que, segundo seu ponto de vista, é degradante e medíocre. Illya, por sua vez, passa dias e noites recebendo seus amantes, dançando e flanando alegremente pelas ruas do porto. Um dos pontos que chama a atenção de Homer é o fato de Illya ser aficionada por teatro e, mais especificamente, pelas tragédias gregas. Para ele, trata-se de uma contradição: como uma prostituta pode gostar de algo tão elevado como a tragédia? Illya, por sua vez, é espectadora assídua de todas as tragédias apresentadas ao longo dos festivais do Teatro de Dionísio. Aos domingos, ela não trabalha, daí o nome do filme: recebe seus amigos e amantes em casa e thes conta os enredos das tragédias que assistiu.

Em uma de suas saídas para assistir tragédias, Illya é acompanhada pelo intelectual que, intrigado, quer compreender esse seu interesse cultural. Por meio do travelling da câmera, podemos ver as reações de todos os espectadores e de Illya ao longo do espetáculo. A tragédia apresentada é Medeia e, enquanto a feiticeira pragueja contra Jasão logo nos primeiros momentos da obra, os espectadores assistem à cena tranquilamente. Illya chora muito. Mais à frente, quando Medeia assassina os dois filhos e amaldiçoa a vida de Jasão, a plateia assiste aterrorizada e em lágrimas. Illya gargalha, quase como se assistisse ao triunfo final da justiça. Terminada a peça, enquanto os atores recebem os aplausos do público, Illya está em extasiada.

Em outro momento do filme, Homer passa a compreender o que acontece com a espectadora Illya, que tem reações em tudo diversas às dos outros espectadores. Nessa cena, a prostituta convida todos os seus amantes para que escutem a história de Medeia. Entre mimos, música, comidas e muita bebida, ela 
se diverte ao contar o enredo da tragédia, enquanto Homer, indignado com a versão de Illya, compartilha seu pasmo junto ao Capitão, mais um dos amantes da prostituta grega:

ILLYA (contando para todos os seus amantes): Medeia é uma peça bonita, mas para vocês, homens, não é muito elogiosa. A peça é sobre o que uma mulher sofre por um homem.

(Homer olha surpreso para o Capitão.)

ILLYA: Era uma vez uma princesa de um reino muito distante. O nome dela era Medeia. Ela era linda, com uma longa cabeleira negra. Um grego chega e, imediatamente, Medeia fica louca por ele. Ela não ouve ninguém, ela o quer... Ela briga com seu pai, com seu país inteiro... Medeia era muito doce, mas, às vezes, tinha um pavio curto.

HOMER (para o Capitão): Doce? Era uma personagem vil, uma assassina!

ILLYA: De qualquer forma, ela vai à Grécia para se casar com esse homem. Ele é um príncipe. Seu nome é (Illya cospe no chão, com desprezo) Jasão. Ela é boa para ele, dá a ele dois lindos filhos. Mas ele, em seguida, casa com uma princesa loura em Atenas. Esse Jasão não tem nem o cavalheirismo de contar uma mentira para Medeia. Não! Diz, na cara dela, que quer a loura porque ela é uma princesa. Medeia chora e diz "eu sou uma princesa também". É bonito como ela chora. Ela faz tudo por Jasão, até manda presentes para a loura!

HOMER (para o Capitão): Ela manda presentes envenenados!

ILLYA: Mas todos falam mal dela. Eles dizem que ela é uma bruxa. Há doze senhoras ricas em lindos vestidos, mas elas falam mal de Medeia também!

HOMER (para o Capitão): Doze senhoras ricas? O coro grego?

ILLYA: E Medeia chora. Vou te dizer, ela parte o seu coração. Ela está com medo. Ela pega as crianças e as esconde. Mas, no final, Jasão percebe o quanto Medeia o ama. Eles compram uma linda carruagem, ela pega as crianças, e eles todos vão à praia!

HOMER (para o Capitão): Não! É uma tragédia grega, e ela lhe dá um final feliz! Ela nem disse que Medeia matou os filhos!

CAPITÃO: Ela mudou isso também. Ouça, Illya é feliz. Ela tem sua própria maneira de viver. Deixe-a em paz.

HOMER: É impossível, uma prostituta não pode ser feliz. Um mundo prostituído não pode ser feliz. Eu gostaria de alcançar a mente dela. 
CAPITÃO: E o que colocaria lá?

HOMER: Razão no lugar de fantasia. Moralidade ao invés de imoralidade. Eu tenho que educá-la. Transformá-la.

CAPITÃO: Lembre-se do que aconteceu com Pigmalião.

HOMER: Eu não cometeria esse erro. Illya é encantadora. Mas, para mim, ela não é uma mulher, é uma ideia. Ela é uma criminosa, isso sim! (O Capitão ri) E a ordem deve ser restabelecida em toda parte, não vê, Capitão?

CAPITÃO: Eu vejo que você terá olhos vendados por toda a sua vida.

(A câmera focaliza Illya no meio de seus amantes, terminando de contarlhes, agora, Édipo Rei.)

ILLYA: Mas vamos nos esquecer dessas coisas ruins. Machucaram seus olhos, pobrezinho. Mas, no final, ele encontrou sua família, e foram todos juntos à praia!

HOMER (ao Capitão, repetindo a frase de Illya): "E eles foram todos à praia"?

CAPITÃO: Para ela, as tragédias sempre acabam na praia... ${ }^{3}$

É a partir do encontro conflituoso entre duas visões de mundo díspares que se centra o enredo do filme: ao recontar as tragédias gregas de acordo com seu modo muito particular de ver, mesmo sem querer, Illya afronta Homer, que crê saber o sentido último contido nos enredos trágicos. Entretanto, o que fundamenta e torna o saber dele mais verdadeiro do que o da prostituta? A erudição do intelectual? Observa-se que, de modo oposto à parábola de Diderot, o filme de Dassin vai colocar em xeque justamente a aposta na erudição, na correção moral e na hermenêutica como procedimentos para configurar o olhar e - modo de agir do espectador. Veremos que, para questionar a força da hermenêutica tanto no campo pedagógico como no do saber sobre as tragédias, o filme vai realizar um interessante movimento de modo a poder sabotar certo maquinário constituído por essa posição teórica.

Por que Homer quer converter Illya? A resposta é no mínimo curiosa. Ele quer

${ }^{3}$ NUNCA aos domingos. Direção: Jules Dassin. [S.l.]: Silver Screen, 1960. 1 DVD (91 min). 
convertê-la não para torná-la mais inteligente, nem mais estudiosa, nem mesmo para torná-la semelhante a ele mesmo. Todos esses efeitos são importantes para ele, evidentemente, mas não são seu objetivo primordial. Ele quer convertê-la para torná-la feliz. Ou seja, é atribuindo de largada infelicidade à vida de Illya que Homer, filantropicamente, parte em sua missão educativa. E por que ela é infeliz? De acordo com Homer, antes de mais nada, por ser uma infame, por se corromper moralmente ao trabalhar como prostituta. Depois, por não saber qual o verdadeiro significado dos enredos trágicos, ou seja, ser uma espectadora equivocada em sua leitura. Pois bem, se aceitamos que Nunca aos domingos pode ser lido como um filme fundamentado a partir de um encontro conflituoso entre duas perspectivas teóricas, opondo dois modos de ver radicalmente diversos entre si, pode-se observar que, de acordo com a visão de Homer, a felicidade está diretamente vinculada aos prazeres provenientes da moral e da razão; sua aposta está centrada naquele tipo de razão transcendental que se fundamenta por meio dos pressupostos hermenêuticos, de modo a trabalhar pelo desvelamento dos segredos e sentidos finais das obras e escritos humanos. Portanto, de acordo com a posição de Homer, a ausência de felicidade residiria na falta de capacidade e precisão hermenêutica tanto em relação à moral como aos objetos do conhecimento.

Entretanto, como vimos, Nunca aos domingos não vai operar de modo a replicar o mito de Pigmalião e a peça de Shaw. De modo diverso ao rei de Chipre e Henry Higgins, qual problema o intelectual vai encontrar aqui? Como enuncia o Capitão, é o simples fato de que Illya - a prostituta do Porto de Pireus, a aficionada por tragédias, a narradora dos mitos ao longo das tardes de domingo - já é feliz. É com esse problema que o intelectual, professor e pedagogo de Nunca aos domingos vai se deparar: não se pode tornar feliz alguém que já o é, do mesmo modo que não se pode converter alguém em direção a um ponto em que já se está localizado de antemão. Eis que o filme mobiliza a maquinaria disposta no mito de Pigmalião ao redor do tema do olhar, porém insere engenhosamente uma válvula a mais - a felicidade já obtida de Illya - travando as engrenagens que o sustentam: diferente da estátua que carece de vida, da florista pobre que adere à 
tese de que the falta o refinamento da língua inglesa ou do crítico que sempre está em déficit com sua própria formação, à Illya não falta nada; pelo contrário, ela excede em tudo. Em oposição à visão hermenêutica de Homer, generosa em sua oferta de conversão para uma felicidade por vir, temos a exuberância e a materialidade da felicidade de Illya toda exposta e vinculada diretamente a certo modo outro, muito particular por sinal, de configurar o próprio olhar. Ao travar a maquinaria da relação pedagógica, ao impedir o trabalho de conversão proposto pelo intelectual, o filme acaba sabotando os próprios pressupostos que sustentam o mito de Pigmalião, da peça de Shaw e dos raciocínios do bom crítico diderotiano, e torna a ação de Homer ineficaz ao ponto de quase não transparecer no enredo, enquanto Illya domina a cena e torna-se a grande protagonista da ação.

Afinal, qual modo outro de olhar é esse de Illya que a torna tão potente e the permite recusar, mesmo sem enunciar dessa forma, a oferta de conversão pedagógica? Podemos afirmar, evidentemente, que Illya opera a partir de outro procedimento teórico que não a interpretação. Provisoriamente, aqui nomeamos o gesto dessa espectadora comum como gesto-qualquer, em oposição à determinação e certeza constituintes do gesto hermenêutico. Temos em Illya, portanto, uma nítida manifestação do que chamaremos, provisoriamente, como espectadora qualquer.

"De onde provêm as singularidades quaisquer, qual é o seu reino?" (Agamben, 2013b, p. 13), pergunta o filósofo italiano Giorgio Agamben ${ }^{4}$ em seu livro $A$

\footnotetext{
${ }^{4}$ Agamben, em seu livro A comunidade que vem (2013b), dedica-se demoradamente ao tema do ser qualquer. Em vez de definir o qualquer a partir do sentido "não importa qual, indiferentemente", o filósofo italiano vai preferir a definição latina do adjetivo quodlibet que se refere ao qualquer como o "ser tal que, de todo modo, importa", o "ser qual-se-queira" (p. 10). De acordo com Agamben, radicalmente singular, o ser qualquer pode ser pensado a partir de sua compleição em seu próprio pertencimento, para o seu ser-tal. Por fim, o filósofo identifica a singularidade qualquer ao amável. A perspectiva de Agamben em relação ao ser-qualquer nos interessa muito. Entretanto, tendemos a produzir pensamento a partir do que nomeamos como gestoqualquer a partir do trabalho com arquivos históricos, inspirado no procedimento arqueogenealógico de Michel Foucault e do encontro com fontes empíricas da história do teatro brasileiro que descrevem escândalos acontecidos dentro dos teatros ao longo do século XIX. Nesses estudos, a presença qualquer nos interiores dos teatros diz respeito tanto como aquele ser pensado como baixo, xucro, grosseiro, ignorante, exilado do estatuto de cidadania colonial e republicana, assim como aquela figura que, justamente por não participar do campo de saberes e práticas de certa civilização cristã alicerçada por procedimentos de ordem jurídico-policial, pode agir em uma velocidade outra, gerando gestos de resistência imprevisíveis. Situamos, portanto, o qualquer em duas frentes de pensamento: materializada em um indivíduo posicionado de forma x ou y perante a determinada sociedade; e entendido como potência, gesto, atitude, força, campo de imanência que, nessa direção, pode irromper no corpo e experiência de qualquer um. Para uma expansão do gesto-qualquer em nossas investigações, sugerimos a leitura de nossa produção sobre o assunto (Pimentel, 2018. Pimentel; Aquino, 2017).
} 
comunidade que vem. Para levar adiante sua questão, recorre aos escritos de São Tomás de Aquino a respeito do limbo5. Agamben indica que o espaço dessa singularidade, de acordo com o frade, consistiria na própria especificidade límbica. Tal espaço operaria ao mesmo tempo como a morada e a razão de ser do qualquer. Se o limbo teria solucionado o problema da eternidade para as nobres almas existentes antes de cristo, ele também teria resolvido, para São Tomás, o histórico problema do destino das crianças mortas antes de receberem o batismo. O problema cristão se instauraria a partir da situação de finitude dos natimortos e outros infantes: sem ter nenhuma culpa além do pecado original, deus não poderia conferir a esses seres uma punição aflitiva, tal como a do inferno. O criador teria, portanto, optado por uma punição de caráter privativo: o castigo das crianças não batizadas não seria as maldições infernais, mas sim a perpétua carência da visão de deus.

Ora, eis que essa falta se anularia como insuficiência e se converteria em potência, pois produziria nessas crianças quaisquer um efeito reverso ao dos condenados ao inferno. Uma vez que nenhuma delas teria possibilidade de produzir algum tipo de saber a respeito de sua condição, não haveria sofrimento. Assim como o fato de não poder voar não causaria sofrimento para uma pessoa razoável, o desconhecimento do rosto de deus não poderia gerar amarguras para as crianças quaisquer, habitantes do limbo (Agamben, 2013b). Portanto, a maior punição, a carência da visão de deus, inverte-se em natural alegria: a essas crianças restaria uma vida de demora sem dor no abandono divino. Essa posição qualquer, segundo Agamben, não remeteria nem ao lugar ocupado pelos bemaventurados como os eleitos, nem aos desesperados como os condenados. 0 qualquer seria pleno de uma alegria para sempre não destinável. Essa falta-

\footnotetext{
${ }^{5}$ A mitologia cristã conta que entre a porta do inferno e seus círculos tortuosos está situado o limbo. A Divina Comédia nos apresenta o espanto de Dante, guiado por Virgílio (por sinal ele mesmo um dos habitantes do limbo), ao observar os grandes vultos da Antiguidade perambulando eternamente nesse espaço. Estão lá Homero, Horácio, Ovídio - o autor das Metamorfoses, de onde nos chega a narrativa de Pigmalião Demócrito, Avicena, Averróis e mais tantos outros, incluindo Sócrates e Platão. A explicação da presença dessa gente nobre na borda do inferno é bastante simples: são almas de seres nascidos antes da existência terrena de cristo. Por não terem sido batizados como cristãos e, ao mesmo tempo, não portarem pecado algum além do original, não há justificativa para que sejam condenados ao inferno. Mesmo assim, não podem ascender aos céus por não comungarem do espírito do criador. Diante dessa visão, Dante sente muita pena.
} 
potência que configura seu olhar impede essas crianças de se dirigir em direção a qualquer modo de transcendência, habitando o limbo, terreno da imanência absoluta, espaço sem redenção. Mais próximas da prostituta do que do crítico, por estarem exiladas da verdade final, elas não têm alternativa além de habitar esse espaço qualquer.

Illya, essa mulher qualquer do porto de Pireus, vê, e, a partir de sua relação com as tragédias assistidas que carece do sentido último da obra, convida seus amantes para, diante deles, narrar, recontar os mitos e poetizar com base na sua relação com eles, sempre acompanhada de música, álcool e uma sensualidade compartilhada. Nesse gesto, o que os amantes escutam já não se trata mais do mito de Medeia, representado nos teatros de pedra com máscaras sisudas, ao mesmo tempo que sim, trata-se efetivamente do mito de Medeia, porém agora tornado também um novo conto, urdido a partir do encontro singular entre a história da feiticeira grega e a existência portuária da prostituta e espectadora de tragédias Illya. Uma Medeia-qualquer, se assim pudéssemos nos remeter à produção narrativa de Illya.

Para demarcar de modo mais nítido a singularidade e a diferença desse procedimento-qualquer, esse modo outro de arranjo do olhar em relação à hermenêutica, deve-se observar outro gesto fundamental de Illya ao longo do filme. Após sofrer durante algumas cenas tentando se enquadrar no modo de pensar de Homer, Illya desiste de se adaptar ao intelectual e se tranca em seu quarto. Lá, deita em sua cama, acende um cigarro, arma sua vitrola, canta e observa fotografias de seus amantes. E então, realiza um exercício muito particular: ela dança para si, sem ser observada por ninguém. Illya desacelera a máquina de composição intelectual proposta por Homer e do próprio mito de Pigmalião dançando. Ela restitui o passo de seu próprio movimento intelectual, qualquer, no compasso de uma música que lhe dá prazer e regozijo, sempre para si e apenas para si, sem esperar aval ou consentimento alheio, sem faltas, metas ou expectativas de redenção. Eis aqui novamente, como indicado por Woolf e

${ }^{6}$ Tal como Heiner Müller agiu sobre cânones dramatúrgicos criando suas composições textuais tais como Hamletmachine e Medeamaterial, acoplamos o qualquer às reescrituras de Illya sobre as peças trágicas, do mesmo modo como Müller adicionou aos textos célebres a máquina e a matéria. 
Diderot, o tema de um olhar que se constitui a partir da solidão e se exercita nela. Entretanto, o exercício em nada tem a ver com a edificação intelectual, como visto em Diderot. Está mais afeito às deambulações, à insignificância e às práticas mais vagas, imprecisas, quaisquer, das quais Virginia Woolf nos falava. Trata-se de uma solidão atenta, cautelosa em relação aos próprios sentidos.

É evidente que Illya se presta à vida pública e ao seu ofício, mas nunca aos domingos. Ela assiste às tragédias no teatro junto ao público, mas sempre embalada em sua perspectiva radicalmente singular. E, para repudiar o gesto pedagógico que the retira a potência e recobrar sua pulsão existencial, o sentido que configura seu olhar fresco e vigoroso, ela encontra na dança para si um exercício de revitalização. À ambição da ação do intelectual que fomenta a erudição como estratégia para a edificação de um mundo mais nobre, Illya dança e, dançando sozinha, desacelera a voragem dos saberes para refundar sua existência-qualquer numa itha de pertencimento e satisfação que, provisoriamente, pode ser chamada porto de Pireus, ou teatro, ou quarto. Na realidade, esta ilha consiste na própria constituição singular de seu olhar como vivente.

Poderíamos afirmar que ao final do filme de Jules Dassin haveria também uma conversão, pois o intelectual Homer é quem desiste de seu plano pedagógico e passa a abraçar a vida portuária, com seus delírios e gozos. Talvez o diretor tenha tentado criar, em Nunca aos domingos, um roteiro que concluísse uma tese avessa ao Pigmalião de Shaw: já não seria a florista, ou a prostituta, que se converteria à civilização moderna e científica, mas sim o cientista que, voltando a si mesmo o olhar, dar-se-ia conta de que seria outra a vida mais verdadeira. Há que se ter certa ressalva em relação à essa tese, principalmente quando se quer problematizar ou se esquivar do procedimento hermenêutico. Não se trata de propor que o olhar de Illya, dessa espectadora qualquer, seja mais verdadeiro do que o olhar do intelectual. Defender essa hipótese redundaria no mesmo apelo cognitivo presente no procedimento hermenêutico que se detém sobre a distinção entre o acerto e o engano. Trata-se, no caso de Illya, justamente do acontecimento de um procedimento teórico outro, um movimento que já não se sustenta mais 
na discussão sobre um modo de ver mais verdadeiro ou não, mas funda outra lógica de composição do olhar.

Diferente do que se passa ao longo das meditações de Aristo ou na peça de Shaw, Illya nada trabalha para converter o intelectual para seu mundo, pois não se interessa em debater sobre quem está certo ou errado a partir de critérios que nos remetem diretamente a um campo de transcendência. Illya se afasta do procedimento que resvala nos grandes essenciais e nos remete a campos exteriores, tais como a verdade, a moral, a virtude etc., e passa a transitar - e a dançar — desde um campo de imanência. Ela só acompanha o intelectual e, nessa parceria, lado a lado, no cotidiano dos sete dias de uma semana, coexiste com seu mundo e sua perspectiva em diálogo e atrito com Homer. Ela não age em direção a ele movida por nenhum intuito pedagógico, nenhuma lição, nenhum devir transcendente, a não ser a exposição inevitável de seu cotidiano e do modo como narra o mundo e as tragédias gregas que orbitam ao seu redor. E é esse modo que se mostra mais forte e vigoroso para o intelectual do que sua ciência civilizatória, ao ponto de abandonar suas crenças para topar entrar em sua dança. Uma vez mais o que se observa é o encontro e o enfrentamento radical entre procedimentos, modos de existir, arranjos do olhar. Nesse sentido, Nunca aos domingos não nos apresenta a inversão do mito de Pigmalião, simplesmente porque não há uma atitude pedagógica de conversão em ato. Trazendo à cena a felicidade constitutiva da prostituta e espectadora de tragédias Illya, o filme funda uma outra linha conflituosa - a recusa de largada da tutela da conduta alheia inexistente tanto na peça de Shaw quanto no centro da fábula grega.

Como se deve ler um livro? foi a pergunta que nos conduziu a essa breve deambulação sobre o teatro. Se tentamos apresentar duas imagens de modos de olhar distintos entre si, afirmamos novamente que não foi no intuito de sublinhar algum como mais verdadeiro do que o outro. Trata-se apenas de diferentes procedimentos, práticas de formação e efeitos em relação à realidade. E também 
em relação à existência. Em seu ensaio, Woolf não chega a um termo definitivo à sua questão sobre a defesa de um modo de ler em prol de outro e apenas partilha alguns exercícios que acredita serem vigorosos como tentativa de sustentação da potência que atribui ao corpo do leitor comum. Como Woolf, confiamos na força presente naquelas vozes ativas que topam em permanecer na inexatidão. Ecoando seu ensaio, também acreditamos que, talvez, valha a pena ouvir outras histórias nascidas do encontro entre uma pessoa, leitora/espectadora qualquer, e os livros e ações cênicas produzidas no mundo. E lembramos aos que quiserem se aventurar, corpos engajados em estruturas de pensamento demasiado rígidas em regras e na perseguição do juízo final sobre as obras e coisas do mundo, que é possível exercitar-se em outros modos de olhar. Seria preciso, no entanto, começar encontrando em si, para si e por prazer, o limbo configurado. Uma tentativa.

\section{Referências}

AGAMBEN, Giorgio. O homem sem conteúdo. Belo Horizonte: Autêntica Editora, 2013a.

AGAMBEN, Giorgio. A comunidade que vem. Belo Horizonte: Autêntica Editora, 2013b.

DIDEROT, Denis. Discurso sobre a poesia dramática. São Paulo: Cosac Naify, 2005.

DIDEROT, Denis. Paradoxo sobre o comediante. São Paulo: Editora Escala, 2006.

OVÍDIO. Metamorfoses. São Paulo: Editora 34, 2017.

PIMENTEL, Luiz Paulo; AQUINO, Julio Groppa. Um qualquer espectador: notas sobre um escândalo teatral. In: Sala Preta, v. 17, n. 1, p. 147-167, 2017.

PIMENTEL, Luiz Paulo. Do governo das patas: um estudo sobre a emergência do espectador crítico no teatro brasileiro. 2018, 225p. Dissertação (Mestre em Filosofia da Educação) - Faculdade de Educação, Universidade de São Paulo, São Paulo, 2018.

SHAW, George Bernard. Pigmaleão. Porto Alegre: L\&PM, 2011. 


\section{Urdimento}

Um crítico e uma prostituta: Incursões do pensamento em direção ao espectador qualquer

WOOLF, Virginia. O valor do riso e outros ensaios. São Paulo: Cosac Naify, 2014.

Recebido em: 05/01/2021

Aprovado em: 16/02/2021

Universidade do Estado de Santa Catarina - UDESC

Programa de Pós-Graduação em Teatro - PPGT Centro de Arte - CEART

Urdimento - Revista de Estudos em Artes Cênicas

Urdimento.ceart@udesc.br 